\title{
How is Consumer Financial Capability Measured?
}

\author{
Julie Birkenmaier ${ }^{1}$ (D) David Rothwell ${ }^{2}$ (D) Mary Agar $^{3}$ (D)
}

Accepted: 27 January 2022 / Published online: 10 February 2022

(c) The Author(s), under exclusive licence to Springer Science+Business Media, LLC, part of Springer Nature 2022

\begin{abstract}
The research literature on the growing field of consumer financial capability displays a wide diversity of understanding about the meaning and measurement of the concept. While sufficient research literature has been produced for a review of measurement domains and indicators, this work remains undone. The aim of the study is to assess the quantitative peer-reviewed research literature to advance the field toward building an evidence base for financial capability interventions and policies to improve family financial well-being and reduce economic inequality. This scoping review study analyzed the financial capability scholarly literature between 2015 and 2018. Overall, 34 studies used quantitative data and met all inclusion criteria for this study. Findings suggest that financial capability measurement constructs were operationalized in 12 different ways $(n=22)$. Most commonly, financial capability was operationalized as the combination of objective financial knowledge and financial access. Few studies included measurement of financial socialization or financial well-being. Most studies measured financial access using only formal financial access measures, such as bank account ownership and/or whether the consumer has investments. A smaller number of studies measured both formal and informal access (including use of non-bank financial institutions/products). Half of the articles that included financial access used bank account either solely or in combination with other measures as the indicator(s). Many studies lacked any measure of financial access. Recommendations are made about standardizing measurement for the constructs within financial capability and measurement of financial capability.
\end{abstract}

Keywords Financial capability $\cdot$ Financial access $\cdot$ Financial knowledge $\cdot$ Financial socialization $\cdot$ Financial wellbeing

\section{Introduction}

Research on family finances has never been more important in the era of declining real wages, increasing income volatility, and increasing financial unpredictability for all

This is one of several papers published together in Journal of Family and Economic Issues on the "Special Issue on the Financial capability and asset building".

Julie Birkenmaier

Julie.Birkenmaier@slu.edu

David Rothwell

David.Rothwell@oregonstate.edu

Mary Agar

Agar@uga.edu

1 Saint Louis University School of Social Work, 3550 Lindell Blvd., St Louis, MO 63103, USA

2 College of Public Health and Human Sciences, Waldo Hall 462, 2250 SW Jefferson Way, Corvallis, OR. 97331, USA

3 School of Social Work, University of Georgia, 279 Williams Street, Athens, GA 30602, USA but higher-income families (Aspen Institute, 2016; Turbeville, 2015). Global events occurring in mid-2020, including exposure of racial inequity in the U.S. that ignited social justice movements around the world, and the COVID-19 global pandemic and its associated record-high unemployment rate and economic uncertainty (Shambaugh, 2020), provide further impetus for research into financial capability. The importance of financial capability has been underscored by its identification as a "Grand Challenge" by the social work profession (Sherraden et al., 2015). Research is needed about financial capability as a concept as well as related interventions designed to assist consumers with their personal finances.

The term "consumer financial capability" is used widely both within and across disciplines. As a concept, it describes various related ideas, including the degree to which consumers exhibit strong financial management behaviors (De Meza, 2008; Money \& Pensions Service, 2020), and/ or the potential or capacity consumers have for exhibiting effective financial management behaviors (Friedline \& West, 2016, 2016; Prosperity Now, 2020a; Sherraden, 
2013). Interventions designed to develop consumer financial capability by either building financial management skills or increasing their capacity for strong financial management behaviors through knowledge, skills, self-efficacy, and resolving emotional difficulties include: financial education, financial counseling and coaching, credit counseling and building, assisting people to access safe and affordable financial products and services, tax preparation, accessing federal and state benefits, incentivized savings programs, financial therapy, and asset ownership programs (Archuleta \& Grable, 2011; Callahan et al., 2020; Prosperity Now, 2020b; Sherraden et al., 2016). These interventions take place in a variety of settings such as schools, workplaces, online, community organizations, and elsewhere.

Although no formal review has yet been published on this topic, a cursory review reveals that the conceptual, descriptive, and explanatory literature on financial capability displays a wide diversity of understanding about the meaning and measurement of the concept. Such lack of standardization about the concept and measurement poses a barrier to moving the research on this important topic forward. Financial capability is a fairly recent framework and is still under development as researchers have begun to empirically demonstrate the framework and suggest refinements that can be tested. Standardization of measurement domains and indicators would allow for internal consistency of findings and replication among studies, which can ultimately advance understanding of the causal and other dynamic relationships among constructs. Without consensus on the meaning of the concept and measurement, scholars may actually be researching different phenomena, and are therefore unable to make clear decisions about important predictors and relationships among variables. Lack of consistent measurement also poses a barrier to testing the theory of financial capability. Ultimately, evaluating the efficacy of interventions designed to build consumer financial capability relies on harmonized measurement of core constructs and improved understanding of their connections (or lack thereof). Standardization also protects against researcher bias about the best measurement (Epstein \& Timmermans, 2018). Furthermore, research on financial capability is published in interdisciplinary journals and by researchers in many disciplines, thus compelling consensus across disciplines.

This study, a scoping review of recent consumer financial capability research literature, seeks to fill the gap and move this effort forward with findings about the measurement of consumer financial capability overall, and its components. The aim of this review is to refine scholarly understanding of how financial capability is measured in order to advance an evidence base for interventions and policies to improve financial well-being and reduce economic inequality. Given that the general understanding of a concept is directly related to the operational definition, or way in which a concept is measured, we next review the conceptual framework for financial capability, including key definitions of its constructs. In this article focused on both family and consumer financial capability, for clarity, the broader term "consumer" will be used to encompass both the individual and family functioning as a consumer.

\section{Background}

\section{Financial Capability: The Conceptual Framework}

This study uses the financial capability conceptual framework as theorized by Sherraden $(2013,2017)$. This framework, demonstrated empirically by Huang et al. (2013), suggests that financial capability operationalizes one's capacity to achieve financial well-being for them and their families, and is comprised of two main components: financial access and financial literacy. Financial capability combines both opportunity to financially act (i.e., financial access) with one's intrinsic ability to financially act (i.e., financial literacy) that results in financial management behavior and financial well-being and, as such, relies heavily on Amartya Sen's foundational theory of capabilities (Caplan et al., 2018; Sen, 2001).

Figure 1 displays Sherraden's (2013) theory in a model format. As seen in Fig. 1, socialization, education and guidance influence financial literacy, or one's ability to act, which interacts with financial access. The opportunity to act, or financial access, is the availability of appropriate financial products and services that provides the platform on which to take financial actions. Therefore, the ability and opportunity to act, in interaction, are the essential components of financial capability, or one's potential for action. This interaction influences financial behavior, which is associated with financial well-being. Although not in Fig. 1, the social and economic structures and institutions in society, such as the education system and the economy, shape institutional conditions and the availability of appropriate financial products and services. These structures and institutions result in unequal opportunity, resources and access for various populations, such as those with low incomes and without legal citizenship. The following subsections describe the components of the financial capability framework.

\section{Financial Socialization}

Family financial socialization, defined as the informal and formal teaching by parents about personal finances that occurs during childhood and adolescence, is recognized as being the most influential type of socialization on adult financial well-being (Pandy et al., 2020; Serido et al., 2010; Shim et al., 2010). Such socialization occurs 


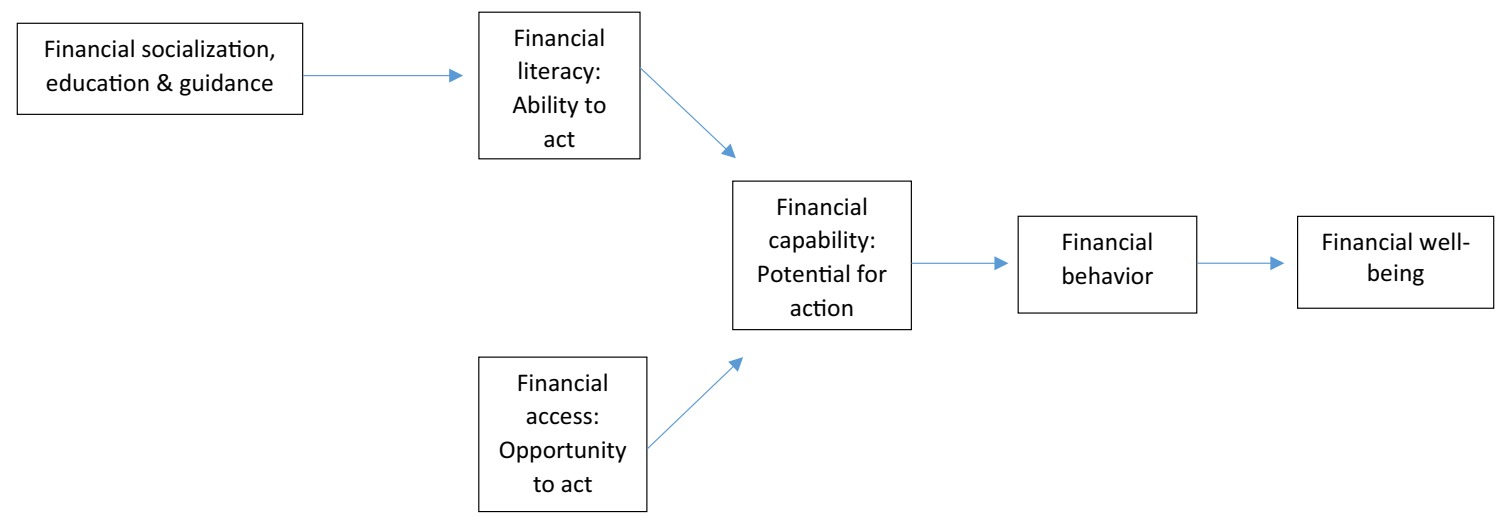

From Sherraden, M. (2013). "Building Blocks of Financial Capability".

Fig. $1 \ldots$

through parent-child communication of financial topics and discussion, modeling and parental expectations (Jorgensen \& Savla, 2010; Jorgensen et al., 2017; Pandy et al., 2020; Serido et al., 2010). Parental financial socialization has been found to be associated with children's later financial behavior (Chowa \& Despard, 2014; Jorgensen et al., 2017) and a more powerful predictor of youth financial well-being than peers, the media, and schools (Pinto et al., 2005). Parental financial socialization can occur from childhood into adulthood and continues to be a powerful influence on financial capability for adults (Marchant \& Harrison, 2020). Nonparental financial socialization takes place in workplaces, schools, and via community organizations.

Financial Socialization Measurement Measurement of financial socialization occurs in a variety of ways. Researchers measure parental financial socialization through variables related to parent-child interaction, communication, and relationships, as well as the degree to which financial socialization was intentional through teaching, modeling, and practice (Gudmunson \& Danes, 2011). However, measurement has often excluded socialization agents that can occur later in the lifespan, such as long-term romantic partners, other peers, the media, and one's children experiencing financial socialization in school or the workplace. Indirect influences on financial socialization, such as experiential learning through access to financial institutions, is another area that needs further measurement exploration (Gudmunson et al., 2016; LeBaron \& Kelley, 2020).

\section{Financial Literacy and Knowledge}

Although there is no universally accepted definition, financial literacy is generally understood as a noun and verb: it is both synonymous with financial knowledge (Huston, 2010) and with the ability to use financial knowledge and skills to effectively manage financial resources (Huston, 2010; Servon \& Kaestner, 2008). In the latter case, it requires financial knowledge as well as skills (CFPB, 2015). Factors that influence financial literacy are education, financial knowledge, attitude and behavior, income, and investments (Santini et al., 2019).

The extent to which a relationship exists between financial literacy and financial behavior is unclear, as increased financial literacy has not shown a relationship between later financial behavior (Fernandes et al., 2014; Miller et al., 2014a, 2014b). However, some components of financial literacy may predict financial well-being, such as attitude towards money (Pandy et al., 2020), and some research has found positive effects of financial literacy on wealth accumulation (van Rooij et al., 2012), lower debt and better loan conditions (Huston, 2012; Lusardi \& Tufano, 2015), and retirement readiness (Lusardi \& Mitchell, 2017). While the Consumer Financial Protection Bureau (CFPB), the major government consumer protection agency in the U.S., has called for financial well-being to be the goal of financial literacy (CFPB, 2015), the sum of the research thus far has demonstrated a mixed relationship between the two (Pandy et al., 2020), thus it is unclear whether financial literacy and knowledge contributes to financial well-being.

Financial Literacy and Knowledge Measurement The domains of financial knowledge most common in finan- 
cial literacy research are the personal finance basics of: (1) money basics (e.g., time value of money, purchasing power); (2) borrowing (e.g., use of credit cards, consumer loans); (3) saving/investing (e.g., use of saving accounts, stocks, bonds, mutual fund); and (4) consumer protection (e.g., use of insurance or other risk management techniques) (Huston, 2010; Lusardi \& Mitchell, 2008). Many studies use three well-known financial knowledge questions covering compound interest, inflation, and investment risk (Lusardi et al., 2011). In addition to or in place of objective measures, studies also use self-perceived subjective measures of financial knowledge (Cude et al, 2016). A new scale of financial literacy that reflects the three domains of financial skill, self-efficacy, and explicit knowledge is a recent measurement advance (Warmath \& Zimmerman, 2019).

\section{Financial Access}

Consumer financial access has been demonstrated to be a critical component of financial capability concept (Huang $\&$ Sherraden, 2019). Consumer financial access is defined as the ability and choice to open, afford, and continuously use beneficial financial products and services from banks, credit unions, insurance companies, and other mainstream financial institutions (Birkenmaier et al., 2019). These institutions undergo strict government oversight of their operations, including customer charges, and have consumer protections attached to them. Products and services from formal institutions facilitate saving and transactions, investments, use of credit, and risk management that enable individuals to meet (un)expected financial needs, grow their wealth, and be financially secure throughout their lifetime (The World Bank, 2019).

Financial Access Measurement In the scholarly literature, financial access is measured with a wide range of indicators, from simply owning a bank account to combinations of some factors (Apaam et al., 2018; Birkenmaier \& Fu, 2016a, 2016b; Huang, Kim, et al., 2016; Huang, Nam, et al., 2016; Karp \& Nash-Stacey, 2015; The World Bank, 2012, 2019). In a narrow view, consumer financial access is measured as having access to transaction products and services to deposit money, obtain cash, pay bills, transmit money domestically and internationally, and the opportunity to save money in an insured account (Apaam et al., 2018; Huang, Nam, et al., 2016; Huang, Kim, et al., 2016). A broader view is used when researchers measure an array of financial products and services, such as ownership of savings accounts, credit cards, mortgage and small business loans, and small-dollar consumer loans for financial access (Gardeva \& Rhyne, 2011). Small-dollar and large-dollar consumer credit is needed for consumers to borrow money for both consumption and wealth-building purposes, such as building small businesses, purchasing homes, and building credit (Apaam et al., 2018). Other aspects of consumer financial access included in measurement has included emergency savings (protection against financial risk through insurance (e.g., health, auto, and life)) and investment opportunities (e.g., retirement accounts) (Collins \& Gjertson, 2013; The World Bank, 2019; White House Council of Economic Advisors, 2016).

\section{Financial Management Behavior}

Within the context of a growing non-bank financial services industry (Clarity Services Inc., 2020), more precarious finances for many consumers due to wage stagnation and lack of a living wage, growing income and wealth inequality and asset poverty for families with children, and growing income volatility (Cooper et al., 2019; Rothwell et al., 2019; Federal Reserve Bank of St. Louis, 2019; Pew Charitable Trusts, 2017), the need for strong financial management skills has become increasingly important. Financial management behavior is conceptualized as behaviors related to consumption (managing shopping and purchases), cash management (i.e., how individuals manage and record their cash purchases), savings and investment (i.e., saving, planning for retirement, investing money), and credit management (how individuals use their credit cards and repay loans) (Dew \& Xiao, 2011; Ksendzova et al., 2017). Financial management behavior is especially important for low-income consumers and families, and other financially vulnerable populations that have less room for error (Miller et al., 2014a, 2014b; Mitchell \& Lusardi, 2015; Xiao, 2016). Previous research has indicated that financial management behaviors are associated with a range of financial outcomes, such as financial well-being (Dew \& Xiao, 2011; Xiao et al., 2009) and financial satisfaction (Xiao et al., 2014).

Financial Management Behavior Measurement Researchers exhibit diversity in their measurement of financial management behaviors, such as measuring specific behaviors (e.g., the act of saving or budgeting), and specific outcomes (e.g., having higher retirement savings). Researchers also measure single acts (e.g., using cash for a purchase) and repeated acts (e.g., reviewing monthly bills over time) (Xiao, 2008). Dew and Xiao (2011) have recently developed and validated a scale that include the subscales of cash management, credit management, savings and investment, and insurance that is highly predictive of levels of savings and debt.

\section{Financial Well-being}

Financial well-being has been the topic of increased attention from researchers and in the realm of public policy 
(CFPB, 2015; Fu, 2020). Financial well-being is defined as a state of being in which people have control over their daily finances, are resilient when unexpected changes in finances occur, are making progress toward financial goals, and can make choices to enjoy life (CFPB, 2015, p.5). The concept also includes the dimension of money management stress and being able to manage current finances to meet obligations and expected future financial security and meeting future financial goals (Netemeyer et al., 2018). Financial well-being has been associated with consumer work productivity and overall well-being, and the development of a healthy economy (Diener \& Biswas-Diener, 2002; Kim \& Garman, 2003; Netemeyer et al., 2018). Financial well-being has also been negatively associated in the literature with stress and mental health symptoms (Hojman et al., 2016). At the societal level, financial well-being serves as an indicator of lack of poverty, good health and well-being, reduced inequalities, and strong institutions (Fu, 2020).

Financial Well-being Measurement In the past, researchers have measured financial well-being using objective and subjective wellbeing separately or in combination. Objective approaches include using debt level, liquidity management, and financial ratios. Subjective approaches have included financial satisfaction and subjective assessment of one's financial status (Lee et al., 2020). While there is still no universal approach, more recent measurement has often used subjective assessment of the CFPB financial well-being scale. This scale includes items that cover four elements of financial well-being: control over finances, capacity to absorb a financial shock, being on track to meet financial goals, and having the financial freedom to enjoy life (CFPB, 2017).

\section{Rationale and Research Questions for This Study}

In recent years, research on consumer financial capability has proliferated across a range of disciplines. There is now an accumulation of published work sufficient to allow a systematic review of the literature. The goal of this review is to highlight conceptual similarities, identify inconsistencies, assess concept measurement, and chart recommendations for the future of consumer financial capability. This scoping review of recent quantitative research literature on consumer financial capability will critically appraise the state of financial capability research and provide guidance to move it forward. We use the conceptual framework of financial capability by Sherraden (2013) because it provides one of the most cited and widely recognized unified frameworks for financial capability. Specifically, using the Sherraden (2013) framework of consumer financial capability, the main research question is: How is financial capability and its components measured in the quantitative peer-reviewed scholarly literature?

\section{Methods}

\section{Design}

As part of a larger project that examined financial inclusion and exclusion, financial access and financial capability measurement, the researchers undertook a scoping review of the peer-reviewed scholarly literature about consumer financial capability. A scoping review is a systematic search and examination of a topic to gain an overview or understanding of a broad field, as it serves to synthesize large amounts of scholarly findings into a practical and useful format (Colquhoun et al., 2014). The research team was comprised of three faculty members and one graduate student, who engaged the four-step process of search, selection, screening, and analysis (Arksey \& O’Malley, 2005).

\section{Data Search}

The research team used a range of terms related to financial and economic capability, inclusion/exclusion, and financial access. Data were collected from October 10, 2018 until November 8, 2018, using 13 terms: "financial access", "financial capability", "financial inclusion", "financial exclusion", "financial attachment", "bank access", "bank inclusion", "bank exclusion", "bank attachment", "economic access", "economic inclusion", "economic exclusion", and "economic attachment". Seven social work, law, and multidisciplinary databases (that included consumer sciences, human development and family sciences, psychology and business) were searched: Social Science Citation Index, Social Services Abstracts, Social Work Abstracts, Heinonline, Index to Legal Periodicals \& Books Full Text, Dissertations Abstract International, and Google Scholar. Filters of title, abstract, and subject were applied if available; otherwise, a full text search was conducted. The time limit filter was used including month and year or just year (Nov. 2015-2018) when available. The total raw number of results from all of the databases was $N_{l}=4331$. The research team imported these references into EndNote, minus a group of irrelevant references and references in a language other than English. The final number of imported references was $N_{2}=4170$. The vast majority of these emerged from Google Scholar rather than targeted scientific databases. Table 1 provides a summary of the databases, filters, and number of selections. 
Table 1 Data search: databases and filters

\begin{tabular}{|c|c|c|c|c|}
\hline DB type & Databases $^{\mathrm{a}}$ & Applied filters & \# of hits ${ }^{b}$ & $\begin{array}{l}\text { \# of } \\
\text { imported } \\
\text { references }\end{array}$ \\
\hline \multirow[t]{3}{*}{ Social work } & Social Science Citation Index & Title, subject & 403 & 403 \\
\hline & Social Services Abstracts & Title, subject, abstract & 46 & 46 \\
\hline & Social Work Abstracts & Title, subject, abstract & 14 & 14 \\
\hline \multirow[t]{2}{*}{ Law } & Heinonline (Collection: Law Journal Library) & Basic (Text) & 910 & 861 \\
\hline & $\begin{array}{l}\text { Index to Legal Periodicals \& Books Full Text (H.W. } \\
\text { Wilson) }\end{array}$ & Title, subject, abstract & 15 & 15 \\
\hline \multirow[t]{3}{*}{ Multi } & Dissertation \& Theses Global & Title, subject, abstract & 125 & 125 \\
\hline & Google Scholar & Title & 2818 & 2706 \\
\hline & SUM & & 4331 & 4170 \\
\hline
\end{tabular}

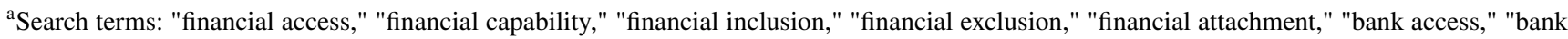
inclusion," "bank exclusion," "bank attachment," "economic access," "economic inclusion," "economic exclusion," "economic attachment"

${ }^{b}$ Number of hits and number of imported data include duplicates

${ }^{\mathrm{c}}$ Among the all references, only highly relevant results were imported to our database

Table 2 Data cleaning

\begin{tabular}{ll}
\hline Type & $\begin{array}{l}\text { Number of } \\
\text { references }\end{array}$ \\
\hline Initial entire references & 4170 \\
Duplicates & \\
By Endnote & -426 \\
By hand & -154 \\
Unrelated references & \\
Internet news & -180 \\
Other (language, etc.) & -441 \\
Incomplete references & -257 \\
Number of references after cleaning & 2712 \\
\hline
\end{tabular}

\section{Data Selection}

The research team eliminated the duplicates and highly unrelated results from the $N_{2}=4170$ dataset.

(1) Duplicates $(n=580)$ were eliminated in a two-step process by Endnote operation $(n=426)$, and then by hand from Endnote $(n=154)$.

(2) Unrelated references were eliminated $(n=621)$, including Internet news $(n=180)$ and other unrelated references not written in English or obviously unrelated $(n=441)$.

(3) Incomplete references that did not include both author and year in the Endnote library were eliminated $(n=257)$.

This process resulted in $N_{3}=2712$ studies. Table 2 presents summary of the data cleaning process.

\section{Data Screening and Inclusion Criteria}

The study was guided by the following inclusion criteria. First, studies had to appear in a peer reviewed publication that was searchable by the databases chosen. Second, studies had to use quantitative data. This inclusion was determined because the focus on this study was on quantitative measurement. Next, to include roughly comparable political and economic contexts, we narrowed the focus to OECD member countries. The elements of financial capability likely function very differently in middle and low income countries. Fourth, we narrowed the focus to consumer level rather than macro context. Our original search returned several studies that were centered on organizations or countries as the unit of analysis and this was not related to our study objectives. Last, we only included studies that included financial capability or related constructs in the title. The research team screened each title and abstract of the $N_{3}=2712$ for the inclusion criteria. A total of $\mathrm{N}=179$ met the initial review of inclusion criteria and were subjected to full-text review. Of the 96 articles that were fully coded, 62 additional articles were excluded because they did not meet all of the inclusion criteria upon a second review. A total of $N_{4}=34$ studies met all inclusion criteria after this double review process.

\section{Data Analysis}

Articles $\left(N_{4}=34\right)$ were reviewed for the presence/absence of the five core constructs: financial capability, financial knowledge, financial access, financial socialization and financial well-being. These constructs were coded as included $(=1)$ or not included $(=0)$. The constructs may have appeared in the title, abstract, keywords, article, and/or measurement portion of the article. The researchers coded content based on 
each manuscript's explicit and implicit content. For example, using the Sherraden (2013) model of financial capability, if both financial knowledge and financial access were included in the title, the researchers coded "included" for financial capability in the title. Within the domain of financial knowledge/literacy the following were coded: (1) financial knowledge (2) objective financial knowledge (3) subjective financial knowledge (4) financial decisions (5) financial confidence and (6) financial beliefs. Financial access, financial behavior, and perception of financial capability were also coded as components of financial capability. Researchers also extracted data on the wide range of measures used for financial access, including measures of long-term financial access (i.e., mortgage loan/homeownership, investments, borrow money from a bank, certificate of deposit, college savings account, and borrow funds from a bank). Financial socialization was coded for any discussion or measurement of financial education or mentoring. For the domain of financial well-being, feelings about finances was coded. Information about data sources was also extracted and coded. Analysis involved univariate and bivariate descriptions of coded results.

\section{Results}

As seen in Table 3, of the 34 included studies, 22 of them measured financial capability constructs in 12 different ways. The most common operationalization of financial capability was as the combination of objective financial knowledge and financial access $(n=6)$. The majority of these studies in this subgroup measured financial capability as the combination of financial knowledge and financial access $(n=7)$. Nearly two-thirds of the studies (62\%) used survey data or used administrative data. The largest proportion (10 of the 34 articles (29\%)) used the National Financial Capability Study (NFCS), and one study used the Canadian Financial Capability Study.

As shown in Table 4, 27 of the 34 studies measured financial access. Most of the studies measured financial access in the formal financial market, such as whether the consumer has an account at a formal financial institution, and/or whether the consumer has investments. A smaller number measured both formal and informal access (i.e., usage of Alternative Financial Services (AFS), such as pawnshops and check cashing services). Half of the articles that measured financial access used bank account either solely or in combination with other measures. Another 10 articles included measures that presumes a bank account (37\%), (i.e., savings, investments, mortgage loan/homeownership, account balance, use of account to pay bills, retirement, insurance, online and mobile banking). Slightly more than half (56\%) of all studies that measured financial access included long-term access measures (i.e., mortgage loan/ homeownership, investments, certificate of deposit, college
Table 4 Financial access measurement $(n=27)$

\begin{tabular}{ll}
\hline Formal and Informal measurement & Number (\%) \\
\hline Formal financial access only & $21(77)$ \\
Hybrid formal and informal measurement & $6(22)$ \\
Account measurement includes bank account & \\
Bank account used for measurement & $17(63)$ \\
Presumes bank account, but not explicit & $10(37)$ \\
Long-term financial access & 1 \\
Measurement includes long-term access & $15(56)$ \\
\hline
\end{tabular}

Table 3 Financial Capability Measurement $(n=22)$

\begin{tabular}{|c|c|}
\hline Financial capability element combinations & $\begin{array}{l}\text { Articles that measured } \\
\text { financial capability } \\
(\mathrm{n}=22) \\
\text { Number }(\%)\end{array}$ \\
\hline Objective knowledge and financial access & $6(27)$ \\
\hline $\begin{array}{l}\text { Objective and subjective knowledge, behavior, perception of financial capabil- } \\
\text { ity }\end{array}$ & $3(14)$ \\
\hline Financial capability practitioner skills & $2(9)$ \\
\hline Behavior and access & $2(9)$ \\
\hline Decisions, confidence, and access & $1(4)$ \\
\hline Behaviors & $1(4)$ \\
\hline Behaviors and financial beliefs & $1(4)$ \\
\hline Behaviors, objective knowledge and financial decisions & $2(9)$ \\
\hline Objective knowledge, behavior, and feelings about finances & $1(4)$ \\
\hline Objective and subjective knowledge, behavior & $1(4)$ \\
\hline Objective knowledge and behavior & $1(4)$ \\
\hline Objective knowledge & $1(4)$ \\
\hline
\end{tabular}


savings account, and borrow funds from a bank; see Table 4, Column 2).

Table 5 displays information about the inclusion and measurement of financial knowledge within the financial capability studies. The majority of the 30 studies that measured financial knowledge $(n=30)$ measured knowledge as a separate concept from financial capability (63\%). The majority of articles containing financial knowledge measurement (53\%) measured objective knowledge only. A smaller number of studies measured both objective and subjective knowledge (20\%), and financial management behavior only (10\%).

In addition, very few studies included measurement of financial socialization (3\%), or financial well-being (9\%). Regarding financial socialization, one study asked respondents about financial decision-making "support from parent, partner, friend or other" (Winstanley et al., 2018). For financial well-being measurement, two studies measured satisfaction with current financial condition (Ranta \& SalmelaAro, 2018; Xiao \& O'Neill, 2018) and one study measured current material hardship and economic well-being (Huang, Kim, et al., 2016; Huang, Nam, et al., 2016).

\section{Discussion and Implications}

The results of this study provide an overview of the quantitative research literature on financial capability conceptualization and measurement. These findings show that researchers are measuring financial capability in many different ways, reflecting little consensus. Within the body of studies in this scoping review that measure financial capability, either explicitly or implicitly, authors have measured financial capability using nine different components in 12 different combinations. However, the majority of them use the combination of financial knowledge and financial access. Other components include financial-related behavior, perception, skills, decisions, confidence, beliefs, and feelings.

There were commonalities for the measurement of financial access and financial knowledge across the studies.
The measurement of financial access within articles about financial capability most often includes only formal access (e.g., ownership of a bank account rather than also include use of AFS). Measuring access in this way has several limitations. Self-reported bank account ownership fails to reveal the extent to which the account provides access to the financial mainstream. For example, 19\% of households in the U.S. have a bank account and also use AFS (Federal Deposit Insurance Corporation, 2018), and are thereby under-utilizing their banked relationship because they also use non-bank institutions for their banking needs. Using bank account ownership as the measure of financial access also fails to recognize the range of aspects of financial access that contributes to financial stability, such as emergency and long-term savings (Collins \& Gjertson, 2013). The ability to access short-term credit is another key element for many financially vulnerable consumers that is overlooked using only the bank account measure. A majority of the studies used a measure of long-term financial access, such as homeownership or investments, in their financial access measurement. As Sherraden (2013) discussed, including these measures are crucial to gain a fuller understanding of a consumer's ability to withstand financial shocks, and provides a better understanding about a consumer's financial stability than formal access, such as bank account ownership, alone. Most of the articles that measure financial knowledge measure the concept separately from financial capability. For the majority of articles, objective, rather than subjective, knowledge is measured.

Very few of the studies measure financial socialization or financial well-being. Sherraden's (2013) seminal work on this topic discusses both as key elements to financial capability and includes them in her model. For example, on financial socialization, she discussed financial socialization as a "key building block" of financial capability (p. 7). Other studies have shown that financial confidence and selfefficacy matters above and beyond objective financial knowledge in determining financial capability (Rothwell et al., 2019). Financial well-being is a relatively new conceptual
Table 5 Financial knowledge measurement $(n=30)$

\begin{tabular}{ll}
\hline & Number (\%) \\
\hline As related to financial capability & $11(37)$ \\
As part of financial capability & $19(63)$ \\
Separately from financial capability & \\
Construct combinations & $16(53)$ \\
Objective knowledge only & $6(20)$ \\
Objective and subjective knowledge & $2(6)$ \\
Objective knowledge and participation in financial education & $2(6)$ \\
Objective and subjective knowledge, and financial management/behavior & $3(10)$ \\
Financial management/behavior & $1(3)$ \\
Financial management/behavior and financial satisfaction &
\end{tabular}


development and has been promoted through the work of the CFPB's scale development work and subsequent scholarship on the topic (Birkenmaier et al., 2018; CFPB, 2015; Huang \& Guo, 2020; Kempson \& Poppe, 2018). As the outcome construct in the framework, it will be important for future work to connect to measures of financial well-being.

Our overall findings may reflect the nascent growth and development of scholarship on financial capability, as well as available data. The focus of research on financially vulnerable consumers has developed and broadened through "thought leaders". Empirical studies have evolved fairly recently from a focus on financial literacy and income to assets and financial capability (for example, see Sherraden, 2013, 2017; Sherraden et al., 2015, 2016). In other countries, financial capability research and practice has evolved from financial literacy to financial capability to financial wellbeing (Kempson \& Poppe, 2018). Thus, measurements used for financial capability are under continual evolution. Using these results, the challenge to a broader consensus about the conceptualization and measurement of financial capability has not been significantly limited by data source. Most researchers created their own datasets for which they had control over the measurement variables or used FINRA's (US) National Financial Capability Study, which includes a wide variety of variables for both financial access and financial literacy that would allow for a broad measurement of both concepts (Mottola \& Kieffer 2017, 2017).

The majority of financial capability studies did not include any measure of financial access (Jang, 2015; Miller et al., 2014a, 2014b; Mottola \& Kieffer 2017, 2017; Ranta $\&$ Salmela-Aro, 2018). Thus, these studies are only using measures that are indirectly related to the financial products and services actually available and owned/used (i.e., financial perceptions, skills, confidence, behaviors, beliefs, and knowledge) to measure financial capability. This finding indicates a significant difference of the conceptual understanding of financial capability as compared to Sherraden (2013), and without financial access measurement, could be considered a completely different concept altogether.

The many different combinations of elements used to measure financial access also pose a challenge to building a body of evidence about the state of financial capability, and designing interventions aiming to build financial capability. Consensus is needed about the degree to which measurement of AFS usage and measures of long-term access are important to consideration of financial access. Omitting AFS may obscure important information about the degree to which a bank account or other form of formal access is useful to consumers, and whether the AFS industry is meeting needs unmet by formal financial institutions. Omitting measures of long-term access may only provide partial information about access that provides opportunity for long-term wealth creation.

\section{Future Research}

To critically evaluate the utility of Sherraden's (2013) model, more empirical research is needed. A commonly accepted, standard construct measured using stable domains would provide the consistency needed for comparison studies and/or meta-analyses. Using Sherraden's (2013) model, future financial capability studies should include measures of parental and non-parental financial socialization, as well as financial well-being as the outcome of financial capability.

Likewise, research that moves toward standardization of measurement of consumer financial access would be useful to stakeholders, such as policy makers, program managers, and researchers in this area. Currently, financial access is conceptually murky - it can be defined as the ability, choice and use, while measurement is focused on actual ownership of accounts. Future research should test separate measures for these three aspects of financial access. Short-term liquidity and long-term access will provide a more wholistic measurement of financial access.

Although financial knowledge is the most studied component in this constellation, an even more nuanced measurement of financial knowledge is also needed. It is important to clarify for stakeholders whether objective and/or subjective knowledge, "knowledge in action" through financial behavior, participation in financial education and/or or one's financial satisfaction is the focus. Research thus far suggests that both objective and subjective knowledge are important for financial well-being (Rothwell et al., 2016). Future research that tests whether this finding holds up within Sherraden's (2013) model would assist in the standardization efforts.

\section{Limitations}

This study is a descriptive study only that provides an overview of research that used quantitative data during a specified window of time. It is possible that studies published prior to 2015 or after 2018 would significantly affect the findings. Our focus in this review rests at the conceptual and measurement level, and empirical analyses of the validity and reliability of constructs is for future work. It is possible our search strategy missed studies from other disciplines who may be studying these topics but using different terminology. This study also excluded qualitative research on financial capability, which may give further insight on conceptualization. Recognizing that financial capability involves complex mechanisms, future research could also consider how psychological (stress, risk preferences) and social processes (cultural norms) work in conjunction with financial capability to explain financial wellbeing. 


\section{Conclusion}

Measurement within scholarly work on financial capability appears to be in a nascent stage. However, the combination of financial knowledge and access is the most common. Using the Sherraden (2013) framework, consideration of financial access as an important domain should be considered in financial capability studies, and a more complex view of access is needed. Although potentially important, financial socialization is also understudied within financial capability studies. The variety of combinations of constructs reflects a lack of conceptual consensus and standardization of the measurement, which impedes research progress and detracts from a deeper understanding of financial capability theory and practice. Similar to efforts to develop "core outcomes" in other fields (Clarke \& Williamson, 2015; Williamson et al., 2012), scholars and practitioners may consider engaging in efforts to develop further consensus on conceptualization and measurement. The use of confirmatory factor analysis and other latent variable measurement techniques to create standard measures would be helpful to move financial capability research forward. Latent variable techniques, such as the study of measurement invariance (or equivalence), can be used to understand the extent to which a given construct is measured across groups. The CFPB's financial wellbeing scale represents a model for how intensive investment in accurate measurement can lead to standardized measurement. In addition to encouraging more consensus, critical reviews and further empirical studies would help to understand the limitations of the current framework.

Funding No funding was used for this project.

Data Availability Data are available from the first author upon request.

Code Availability NA.

\section{Declarations}

Conflict of interest The authors have no relevant financial or non-financial interests to disclose.

Informed Consent This is a review article of previous studies; therefore, no informed consent was needed.

Research Involving Human Participants and/or Animals This is a review article of previous studies, therefore, no ethical approval is required.

\section{Included Studies}

Birkenmaier, J., \& Fu, Q. (2016a). Who uses alternative financial services? A latent class analysis of consumer financial knowledge and behavior. Journal of Social Service Research, 42(3), 412-424. https://doi.org/10.1080/01488376.2016.1147519

Doran, J. K., \& Bagdasaryan, S. (2018). Infusing financial capability and asset building content into a community organizing class. Journal of Social Work Education, 54(1), 122-134. https://doi. org/10.1080/10437797.2015.1043195

Fraczek, B. (2015). The sources of raising money as the factor influencing the level of financial literacy and degree of the financial inclusion. International Journal of Innovative Business Strategies, $1,19$.

Frączek, B. (2016). Usage of internet technology in financial education and financial inclusion by students of economics universities. International Journal of Economics and Management Engineering, 10(9), 3209-3217.

Frączek, B., Bobenič Hintošová, A., Bačová, M., \& Siviček, T. (2017). Simultaneous use of the financial literacy level and the financial inclusion degree as a result of financial education efficiency in Visegrad Group countries. Journal of Economics \& Management, 27, 5-25.

Frey, J. J., Svoboda, D., Sander, R. L., Osteen, P. J., Callahan, C., \& Elkinson, A. (2015). Evaluation of a continuing education training on client financial capability. Journal of Social Work Education, 51(3), 439-456. https://doi.org/10.1080/10437797. 2017.1404523

Friedline, T., \& West, S. (2016). Financial education is not enough: Millennials may need financial capability to demonstrate healthier financial behaviors. Journal of Family and Economic Issues, 37(4), 649-671. https://doi.org/10.1007/s10834-015-9475-y

Grable, J. E., Joo, S. H., \& Park, J. (2015). Exploring the antecedents of financial behavior for Asians and Non-Hispanic Whites: The role of financial capability and locus of control. Journal of Personal Finance, 14(1), 1540-6717.

Huang, J., Nam, Y., \& Lee, E. J. (2015a). Financial capability and economic hardship among low-income older Asian immigrants in a supported employment program. Journal of Family and Economic Issues, 36(2), 239-250. https://doi.org/10.1007/ s10834-014-9398-Z

Huang, J., Nam, Y., Sherraden, M., \& Clancy, M. (2015b). Financial capability and asset accumulation for children's education: Evidence from an experiment of child development accounts. Journal of Consumer Affairs, 49(1), 127-155. https://doi.org/ 10.1111/joca.12054

Huang, J., Nam, Y., Sherraden, M., \& Clancy, M. M. (2016). Improved financial capability can reduce material hardship among mothers. Social Work, 61(4), 313-320. https://doi.org/ $10.1093 / \mathrm{sw} / \mathrm{sww} 052$

Jang, D. H. (2015). The relationship between financial capability and financial stress, with a focus on the users of community welfare centers. International Information Institute (tokyo) Information, 18(5B), 2039.

Johnson, M. A., \& Lamdin, D. J. (2015). Gauging the financial capability of Americans. Business Economics, 50(3), 135-146. https://doi.org/10.1057/be.2015.24

Kim, K. T., \& Lee, J. (2018). Financial literacy and use of payday loans in the United States. Applied Economics Letters, 25(11), 781-784. https://doi.org/10.1080/13504851.2017.1366635

Lamb, L. (2016). Financial exclusion and financial capabilities in Canada. Journal of Financial Economic Policy, 8(2), 212-227. https://doi.org/10.1108/JFEP-06-2015-0037

Lazar, C. M., Black, A. C., McMahon, T. J., Rosenheck, R. A., Ries, R., Ames, D., \& Rosen, M. (2016). All-data approach to 
assessing financial capability in people with psychiatric disabilities. Psychological Assessment, 28(4), 362. https://doi.org/ 10.1037/pas0000179

Loke, V., Birkenmaier, J. M., \& Hageman, S. A. (2017). Financial capability and asset building in the curricula: Student perceptions. Journal of Social Work Education, 53(1), 84-98. https://doi.org/ 10.1080/10437797.2016.1212751

Loke, V., \& Choi, L. (2015). Increasing youth financial capability: A subsample analysis of Asian American and Pacific Islander Participants in the MyPath Savings Initiative. AAPI Nexus: Policy, Practice and Community, 13(1), 45-71.

Loke, V., Choi, L., \& Libby, M. (2015). Increasing youth financial capability: An evaluation of the MyPath savings initiative. Journal of Consumer Affairs, 49(1), 97-126. https://doi.org/10.1111/ joca. 12066

Miller, M., Reichelstein, J., Salas, C., \& Zia, B. (2014a). Can you help someone become financially capable? A meta-analysis of the literature. The World Bank.

Millimet, D. L., McDonough, I. K., \& Fomby, T. B. (2018). Financial capability and food security in extremely vulnerable households. American Journal of Agricultural Economics, 100(4), 1224-1249. https://doi.org/10.1093/ajae/aay029

Mottola, G. R., \& Kieffer, C. N. (2017). Understanding and using data from the National Financial Capability Study. Family and Consumer Sciences Research Journal, 46(1), 31-39. https://doi.org/ $10.1111 /$ fcsr. 12227

Nam, Y., Huang, J., \& Lee, E. J. (2016). Ethnic differences in financial outcomes among low-income older Asian immigrants: A financial capability perspective. Journal of Community Practice, 24(4), 445-461. https://doi.org/10.1080/10705422.2016.1233474

Nam, Y., Lee, E. J., Huang, J., \& Kim, J. (2015). Financial capability, asset ownership, and later-age immigration: Evidence from a sample of low-income older Asian immigrants. Journal of Gerontological Social Work, 58(2), 114-127. https://doi.org/10.1080/ 01634372.2014 .923085

O’Neill, B., \& Xiao, J. J. (2015). Payday loan usage, state law, and financial capability. Journal of Financial Service Professionals, 69(6), 89-98. 1537-1816.

Ranta, M., \& Salmela-Aro, K. (2018). Subjective financial situation and financial capability of young adults in Finland. International Journal of Behavioral Development, 42(6), 525-534. https://doi. org/10.1177/0165025417745382

Rothwell, D. W., Khan, M. N., \& Cherney, K. (2016). Building financial knowledge is not enough: Financial self-efficacy as a mediator in the financial capability of low-income families. Journal of Community Practice, 24(4), 368-388. https://doi.org/10.1080/ 10705422.2016 .1233162

Sanders, C. K. (2016). Promoting financial capability of incarcerated women for community reentry: A call to social workers. Journal of Community Practice, 24(4), 389-409. https://doi.org/10.1080/ 10705422.2016.1233161

West, S., \& Friedline, T. (2016). Coming of age on a shoestring budget: Financial capability and financial behaviors of lower-income millennials. Social Work, 61(4), 305-312. https://doi.org/10.1093/ sw/sww057

Winstanley, M., Durkin, K., Webb, R. T., \& Conti-Ramsden, G. (2018). Financial capability and functional financial literacy in young adults with developmental language disorder. Autism \& Developmental Language Impairments. https://doi.org/10.1177/23969 41518794500

Xiao, J. J., Chen, C., \& Sun, L. (2015). Age differences in consumer financial capability. International Journal of Consumer Studies, 39(4), 387-395. https://doi.org/10.1111/ijcs.12205

Xiao, J. J., \& O'Neill, B. (2016). Consumer financial education and financial capability. International Journal of Consumer Studies, 40(6), 712-721. https://doi.org/10.1111/ijcs.12285
Xiao, J. J., \& O’Neill, B. (2018). Propensity to plan, financial capability, and financial satisfaction. International Journal of Consumer Studies, 42(5), 501-512. https://doi.org/10.1111/ijcs.12461

Yeo, J. H., \& Fisher, P. J. (2017). Mobile financial technology and consumers' financial capability in the United States. Journal of Education \& Social Policy, 7(1), 80-93.

\section{References}

Apaam, G., Burhouse, S., Chu, K., Ernst, K., Fritzdixon, K., Goodstein, R., Lloro, A., Opoku, C., et al. (2018). 2017 FDIC national survey on unbanked and underbanked consumers. Federal Deposit Insurance Corporation.

Archuleta, K. L., \& Grable, J. E. (2011). The future of financial planning and counseling: An introduction to financial therapy. In K. L. Archuleta \& J. E. Grable (Eds.), Financial planning and counseling scales (pp. 33-59). Springer.

Arksey, H., \& O’Malley, L. (2005). Scoping studies: Towards a methodological framework. International Journal of Social Research Methodology, 8(1), 19-32. https://doi.org/10.1080/1364557032 000119616

Aspen Institute. (2016). Income volatility: A primer. Retrieved from https://assets.aspeninstitute.org

Birkenmaier, J. M., Despard, M., Friedline, T., \& Huang, J. (2019). Financial inclusion and financial access. Oxford University Press.

Birkenmaier, J. M., \& Fu, Q. (2016b). The association of Alternative Financial Services usage and financial access: Evidence from the National Financial Capability Study. Journal of Family and Economic Issues, 37(3), 450-460. https://doi.org/10.1007/ s10834-015-9463-2

Birkenmaier, J. M., Sherraden, M., Frey, J. J., Callahan, C., \& Santiago, A. M. (Eds.). (2018). Financial capability and asset building with diverse populations: Improving financial well-being in families and communities. Routledge.

Callahan, C., Jacobson Frey, J., \& Imboden, R. (2020). Overview of interventions. In C. Callahan, J. Jacobson Frey, \& R. Imboden (Eds.), The Routledge handbook on financial social work: Direct practice with vulnerable populations (pp. 7-14). Routledge.

Caplan, M. A., Sherraden, M. S., \& Bae, J. (2018). Financial capability as social investment. Journal of Sociology \& Social Welfare, $45,147$.

Chowa, G. A., \& Despard, M. R. (2014). The influence of parental financial socialization on youth's financial behavior: Evidence from Ghana. Journal of Family and Economic Issues, 35(3), 376-389. https://doi.org/10.1007/s10834-013-9377-9

Clarke, M., \& Williamson, P. (2015). Core outcome sets and trial registries. Trials, 16(1), 1-3. https://doi.org/10.1186/ s13063-015-0738-6

Clarity Services, Inc. (2020). Alternative financial services lending trends: Insights into the industry and its consumers. Retrieved from https://www.clarityservices.com/wp-content/uploads/2020/ 04/2020-AFS-Trends-Report.pdf

Collins, J. M., \& Gjertson, L. (2013). Emergency savings for lowincome consumers. Focus, 30(1), 12-17.

Colquhoun, H. L., Levac, D., O’Brien, K. K., Straus, S., Tricco, A. C., Perrier, L., \& Moher, D. (2014). Scoping reviews: Time for clarity in definition, methods, and reporting. Journal of Clinical Epidemiology, 67(12), 1291-1294. https://doi.org/10.1016/j.jclin epi.2014.03.013

Consumer Financial Protection Bureau [CFPB]. (2015). Financial wellbeing: The goal of financial education. Retrieved from https:// files.consumerfinance.gov/f/201501_cfpb_report_financial-wellbeing.pdf

Consumer Financial Protection Bureau [CFPB]. (2017). CFPB financial well-being scale: Scale development technical report. 
Retrieved from https://www.consumerfinance.gov/data-research/ research-reports/financial-well-being-technical-report/.

Cooper, D., Gould, E., \& Zipperer, B. (2019). Low-wage workers are suffering from a decline in the real value of the federal minimum wage. Economic Policy Institute. Retrieved from https://www.epi. org/publication/labor-day-2019-minimum-wage/

Cude, B. J., Danes, D., \& Kabaci, M. J. (2016). Financial knowledge and financial education of college students. In J. J. Xiao (Ed.), Handbook of consumer financial research (2nd ed., pp. 141-153). New York: Springer.

De Meza, D., Irlenbusch, B., \& Reyniers, D. (2008). Financial capability: A behavioural economics perspective. Consumer Research, 69, 192-193.

Dew, J., \& Xiao, J. J. (2011). The financial management behavior scale: Development and validation. Journal of Financial Counseling and Planning, 22(1), 43-59.

Diener, E., \& Biswas-Diener, R. (2002). Will money increase subjective well-being? Social Indicators Research, 57(2), 119-169. https://doi.org/10.1023/A:1014411319119

Epstein, S., \& Timmermans, S. (2018). Standardization. The Blackwell Encyclopedia of Sociology. Wiley Online Library.

Federal Deposit Insurance Corporation. (2018). 2017 FDIC National survey of unbanked and underbanked households. Retrieved from https://www.fdic.gov/householdsurvey/

Federal Reserve Bank of St. Louis. (2019). What wealth inequality in America looks like: Key facts \& figures. Retrieved from https:// www.stlouisfed.org/open-vault/2019/august/wealth-inequality-inamerica-facts-figures

Fernandes, D., Lynch, J. G., Jr., \& Netemeyer, R. G. (2014). Financial literacy, financial education, and downstream financial behaviors. Management Science, 60(8), 1861-1883. https://doi.org/10.1287/ mnsc. 2013.1849

Friedline, T., \& West, S. (2016). Financial education is not enough: Millennials may need financial capability to demonstrate healthier financial behaviors. Journal of Family and Economic Issues, 37(4), 649-671. https://doi.org/10.1007/s10834-015-9475-y

$\mathrm{Fu}$, J. (2020). Ability or opportunity to act: What shapes financial well-being? World Development, 128, 104843. https://doi.org/ 10.1016/j.worlddev.2019.104843

Gardeva, A., \& Rhyne, E. (2011). Opportunities and obstacles to financial inclusion: Survey report. Washington, DC: Accion, Center for Financial Inclusion. Retrieved from https://centerforfinancialin clusionblog.files.wordpress.com/2011/12/opportunities-and-obsta cles-to-financial-inclusion_110708_final.pdf

Gudmunson, C. G., \& Danes, S. M. (2011). Family financial socialization: Theory and critical review. Journal of Family and Economic Issues, 32(4), 644-667. https://doi.org/10.1007/ s10834-011-9275-y

Gudmunson, C. G., Ray, S. K., \& Xiao, J. J. (2016). Financial socialization. In J. J. Xiao (Ed.), Handbook of consumer financial research (2nd ed., pp. 61-72). Springer.

Hojman, D. A., Miranda, Á., \& Ruiz-Tagle, J. (2016). Debt trajectories and mental health. Social Science \& Medicine, 167, 54-62. https://doi.org/10.1016/j.socscimed.2016.08.027

Huang, J., \& Guo, B. (2020). The financial capability and financial well-being of low-income entrepreneurs. Center for Social Development Research Brief 20-01. Retrieved from https://openschola rship.wustl.edu/cgi/viewcontent.cgi?article $=1901 \&$ context $=$ csd research

Huang, J., Kim, Y., Sherraden, M., \& Clancy, M. (2016). Improved financial capability can reduce material hardship among mothers. Social Work, 61(4), 313-320. https://doi.org/10.1093/sw/sww052

Huang, J., Nam, Y., \& Sherraden, M. S. (2013). Financial knowledge and Child Development Account policy: A test of financial capability. Journal of Consumer Affairs, 47(1), 1-26. https://doi.org/ 10.1093/sw/sww052
Huang, J., \& Sherraden, M. S. (2019). Financial capability and financial well-being: An empirical examination using the CFPB national financial well-being survey. Society for Social Work and Research Annual Program Meeting, San Francisco, CA

Huston, S. J. (2012). Financial literacy and the cost of borrowing. International Journal of Consumer Studies, 36(5), 566-572. https:// doi.org/10.1111/j.1470-6431.2012.01122.x

Huston, S. J. (2010). Measuring financial literacy. The Journal of Consumer Affairs, 44(2), 296-316. https://doi.org/10.1111/j.14706431.2012.01122.x

Jorgensen, B. L., Rappleyea, D. L., Schweichler, J. T., Fang, X., \& Moran, M. E. (2017). The financial behavior of emerging adults: A family financial socialization approach. Journal of Family and Economic Issues, 38(1), 57-69. https://doi.org/10.1111/j.17413729.2010.00616.x

Jorgensen, B. L., \& Savla, J. (2010). Financial literacy of young adults: The importance of parental socialization. Family Relations, 59(4), 465-478. https://doi.org/10.1111/j.1741-3729.2010.00616.x

Karp, N., \& Nash-Stacey, B. W. (2015). Technology, opportunity, \& access: Understanding financial inclusion in the U.S. (Working Paper No. 15/25). BBVA Research. Retrieved from https://www. bbvaresearch.com/wp-content/uploads/2015/07/WP15-25_Finan cialInclusion_MSA.pdf

Kempson, E., \& Poppe, C. (2018). Assessing the levels of financial capability and financial well-being in Ireland. A report to the Competition and Consumer Protection Commission (CCPC), Ireland. Retrieved from https://www.ccpc.ie/business/wp-conte nt/uploads/sites/3/2018/12/Financial-Well-being-in-Ireland-FinalDecember-2018.pdf

Kim, J., \& Garman, E. T. (2003). Financial stress and absenteeism: An empirically derived model. Journal of Financial Counseling and Planning, 14(1), 31-42.

Ksendzova, M., Donnelly, G. E., \& Howell, R. T. (2017). A Brief Money Management Scale and its associations with personality, financial health, and hypothetical debt repayment. Journal of Financial Counseling and Planning, 28(1), 62-75. https://doi.org/ 10.1891/1052-3073.28.1.62

LeBaron, A. B., \& Kelley, H. H. (2020). Financial socialization: A decade in review. Journal of Family and Economic Issues, 42, 195-206. https://doi.org/10.1007/s10834-020-09736-2

Lee, J. M., Lee, J., \& Kim, K. (2020). Consumer financial well-being: Knowledge is not enough. Journal of Family and Economic Issues, 41, 218-228. https://doi.org/10.1007/s10834-019-09649-9

Lusardi, A., \& Mitchell, O. S. (2017). How ordinary consumers make complex economic decisions: Financial literacy and retirement readiness. Quarterly Journal of Finance, 7(03), 1750008. https:// doi.org/10.1142/S2010139217500082

Lusardi, A., \& Mitchell, O. S. (2008). Planning and financial literacy: How do women fare? American Economic Review, 98(2), 413417. https://doi.org/10.1257/aer.98.2.413

Lusardi, A., Schneider, D. J., \& Tufano, P. (2011). Financially fragile households: Evidence and implications (NBER Working Papers: No. 17072). National Bureau of Economic Research. Retrieved from https://www.nber.org/papers/w17072

Lusardi, A., \& Tufano, P. (2015). Debt literacy, financial experiences, and overindebtedness. Journal of Pension Economics \& Finance, 14(4), 332-368. https://doi.org/10.1017/S1474747215000232

Marchant, C., \& Harrison, T. (2020). Emerging adults' financial capability: A financial socialization perspective. International Journal of Consumer Studies, 44(2), 99-110. https://doi.org/10.1111/ijcs. 12548

Miller, M., Reichelstein, J., Salas, C., \& Zia, B. (2014b). Can you help someone become financially capable? A meta-analysis of the literature. The World Bank.

Mitchell, O., \& Lusardi, A. (2015). Financial literacy and economic outcomes: Evidence and policy implications. SSRN. Retrieved 
from https://papers.ssrn.com/sol3/papers.cfm?abstract_id=25687 32

Money \& Pensions Service. (2020). UK strategy for financial wellbeing. Retrieved from https://moneyandpensionsservice.org.uk/ uk-strategy-for-financial-wellbeing/

Mottola, G. R., \& Kieffer, C. N. (2017). Understanding and using data from the National Financial Capability Study. Family and Consumer Sciences Research Journal, 46(1), 31-39. https://doi.org/ 10.1111/fcsr.12227

Netemeyer, R. G., Warmath, D., Fernandes, D., \& Lynch, J. G., Jr. (2018). How am I doing? Perceived financial well-being, its potential antecedents, and its relation to overall well-being. Journal of Consumer Research, 45(1), 68-89. https://doi.org/10.1093/ jer/ucx 109

Pandey, A., Ashta, A., Spiegelman, E., \& Sutan, A. (2020). Catch them young: Impact of financial socialization, financial literacy and attitude towards money on financial well-being of young adults. International Journal of Consumer Studies. https://doi.org/10. 1111/ijcs. 12583

Pew Charitable Trusts. (2017). How income volatility interacts with American families' financial security. Retrieved from https:// www.pewtrusts.org/en/research-and-analysis/issue-briefs/2017/ 03/how-income-volatility-interacts-with-american-families-finan cial-security

Pinto, M. B., Parente, D. H., \& Mansfield, P. M. (2005). Information learned from socialization agents: Its relationship to credit card use. Family and Consumer Sciences Research Journal, 33(4), 357-367. https://doi.org/10.1177/1077727X04274113

Prosperity Now. (2020a). Financial capability. Retrieved from https:// prosperitynow.org/topics/financial-capability

Prosperity Now. (2020b). Financial capability services. Retrieved from https://prosperitynow.org/topics/financial-capability/services

Rothwell, D. W., Ottusch, T., \& Finders, J. K. (2019). Asset poverty among children: A cross-national study of poverty risk. Children and Youth Services Review, 96, 409-419. https://doi.org/10. 1016/j.childyouth.2018.11.045

Rothwell, D. W., \& Wu, S. (2019). Exploring the relationship between financial education and financial knowledge and efficacy: Evidence from the Canadian Financial Capability Survey. Journal of Consumer Affairs, 53(4), 1725-1747. https://doi.org/10.1111/ joca. 12259

Santini, F. D. O., Ladeira, W. J., Mette, F. M. B., \& Ponchio, M. C. (2019). The antecedents and consequences of financial literacy: A meta-analysis. International Journal of Bank Marketing, 37(6), 1462-1479. https://doi.org/10.1108/IJBM-10-2018-0281

Sen, A. (2001). Development as freedom. Oxford Paperbacks.

Serido, J., Shim, S., Mishra, A., \& Tang, C. (2010). Financial parenting, financial coping behaviors, and well-being of emerging adults. Family Relations, 59(4), 453-464. https://doi.org/10. 1111/j.1741-3729.2010.00615.x

Servon, L. J., \& Kaestner, R. (2008). Consumer financial literacy and the impact of online banking on the financial behavior of lowerincome bank customers. Journal of Consumer Affairs, 42(Summer), 271-305. https://doi.org/10.1111/j.1745-6606.2008.00108x

Shambaugh, J. (2020). COVID-19 and the US economy: FAQ o the economic impact \& policy response. Brookings. Retrieved from https://www.brookings.edu/blog/up-front/2020/03/23/covid-19and-the-u-s-economy-faq-on-the-economic-impact-policy-respo nse/

Sherraden, M. S. (2013). Building blocks of financial capability. In J. M. Birkenmaier, M. S. Sherraden, \& J. Curley (Eds.), Financial education and capability: Research, education, policy, and practice (pp. 3-43). Oxford University Press.
Sherraden, M. S. (2017). Financial capability. In C. Franklin (Ed.), Encyclopedia of social work. Oxford University Press.

Sherraden, M. S., Frey, J. J., \& Birkenmaier, J. M. (2016). Financial social work. In J. J. Xiao (Ed.), Handbook of consumer finance research (pp. 115-127). Springer.

Sherraden, M. S., Huang, J., Frey, J. J., Birkenmaier, J. M., Callahan, C., Clancy, M. M., \& Sherraden, M. (2015). Financial capability and asset building for all (Grand Challenges for Social Work Initiative Working Paper No. 13). Cleveland: American Academy of Social Work and Social Welfare. Retrieved from http://aaswsw. org/wp-content/uploads/2015/10/Financial-Capability-and-AssetBuilding-for-All.pdf

Shim, S., Barber, B. L., Card, N. A., Xiao, J. J., \& Serido, J. (2010). Financial socialization of first-year college students: The roles of parents, work, and education. Journal of Youth and Adolescence, 39(12), 1457-1470. https://doi.org/10.1007/252Fs 10964-009-9432-x

The World Bank. (2012). Financial inclusion strategies reference framework. Retrieved from http://documents.worldbank.org/curat ed/en/801151468152092070/pdf/787610WP0P144500use0only0 900A9RD899.pdf

The World Bank. (2019). Financial inclusion: Overview. Retrieved from http://www.worldbank.org/en/topic/financialinclusion/overv iew

Turbeville, W. C. (2015). Financialization and equal opportunity. Demos. Retrieved from http://www.demos.org/publication/finan cialization-equal-opportunity.

Van Rooij, M. C. J., Lusardi, A., \& Alessie, R. (2012). Financial literacy, retirement planning and household wealth. The Economic Journal, 122(560), 449-478. https://doi.org/10.1111/j.1468-0297. 2012.02501.x

Warmath, D., \& Zimmerman, D. (2019). Financial literacy as more than knowledge: The development of a formative scale through the lends of Bloom's Domains of Knowledge. Journal of Consumer Affairs, 53(4), 160-201628. https://doi.org/10.1111/joca. 12286

White House Council of Economic Advisors. (2016). Financial inclusion in the United States. Retrieved from https://obamawhitehouse. archives.gov/blog/2016/06/10/financial-inclusion-united-states

Williamson, P., Altman, D., Blazeby, J., Clarke, M., \& Gargon, E. (2012). Driving up the quality and relevance of research through the use of agreed core outcomes. Journal of Health Services Research \& Policy, 17(1), 1-2. https://doi.org/10.1258/jhsrp. 2011.011131

Xiao, J. J. (2008). Applying behavioral theories to financial behavior. In J. J. Xiao (Ed.), Handbook of consumer finance research (pp. 69-81). Springer.

Xiao, J. J. (2016). Preface. In J. J. Xiao (Ed.), Handbook of consumer finance $(\mathrm{pp} . \mathrm{ix}-\mathrm{x})$. Springer.

Xiao, J. J., Chen, C., \& Chen, F. (2014). Consumer financial capability and financial satisfaction. Social Indicators Research, 118(1), 415-432. https://doi.org/10.1007/s11205-013-0414-8

Xiao, J. J., Tang, C., \& Shim, S. (2009). Acting for happiness: Financial behavior and life satisfaction of college students. Social Indicators Research, 92(1), 53-68. https://doi.org/10.1007/ s11205-008-9288-6

Publisher's Note Springer Nature remains neutral with regard to jurisdictional claims in published maps and institutional affiliations. 